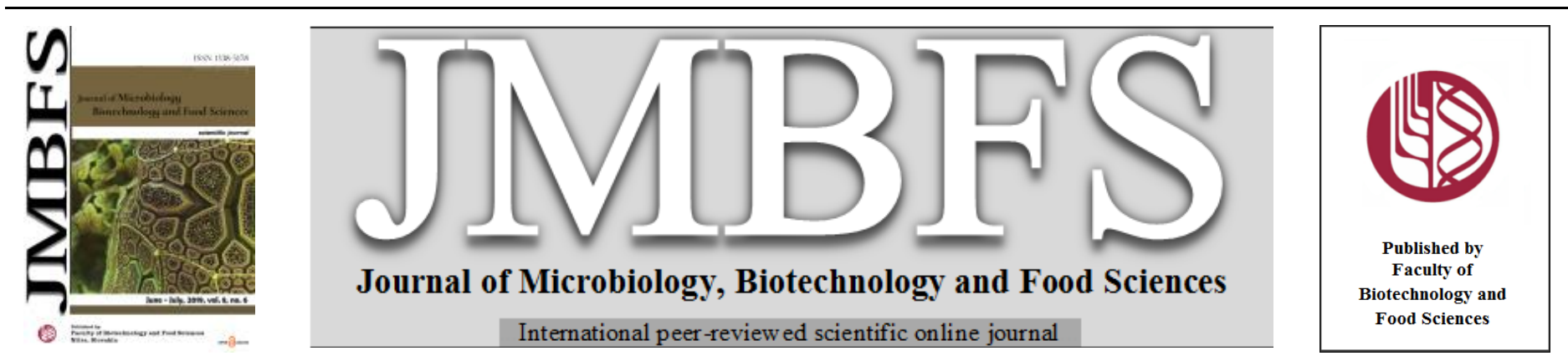

\title{
SOIL AMENDED WITH ORGANIC FERTILIZERS AS A SOURCE OF ACTINOMYCETES WITH HIGH POTENTIAL AS BIOCONTROL AGENTS
}

\author{
Soňa Javoreková*, Silvia Kovácsová, Juraj Medo, Jana Maková, Jana Petrová, Lukáš Hleba, Daniela Koštálová, Renata Cinkocki
}

Address(es): prof. Ing. Soňa Javoreková, PhD.,

Department of Microbiology, Faculty of Biotechnology and Food Sciences, Slovak University of Agriculture, Nitra, Slovakia

*Corresponding author: sona.javorekova@uniag.sk

doi: 10.15414/jmbfs.2019.8.6.1352-1359

\section{ARTICLE INFO}

Received 15. 11. 2018

Revised 19. 2. 2019

Accepted 23. 2. 2019

Published 1. 6. 2019

Regular article open $\mathcal{O}$ access

\begin{abstract}
Plant diseases caused by pathogenic fungi are a severe problem for agriculture, and some organic fertilizers have shown a suppressive capacity due to the antagonistic action of microbial communities inhabiting those substrates. The purpose of this work was to isolate and identify actinomycetes from soil, compost and vermicompost able to antagonize phytopathogens. In total, out of 352 actinomycetes successfully recovered on Pochon medium and of which were selected representative 22 mycelium forming isolates, which were subjected to morphological and genotypic characterization. Genetic characterization based on 16S rDNA fragment sequencing revealed that, all the actinomycete isolates belong to the genus Streptomyces. The antifungal activity of isolates was tested against eight phytopathogenic fungi, and they were most activated against Rhizoctonia solani, Alternaria tenuissima, Aspergillus niger and Penicillium expansum. Isolates 51VK13 (Streptomyces sampsonii) and 12VK13 (Streptomyces flavovariabilis)-isolated from soil amended with vermicompost showed the greatest antagonistic activity. Their bioactive potential was also confirmed by presence of genes for nonribosomal peptide synthetase (NRPS) and polyketide synthase types I and II (PKS-I and PKS-II). It can, therefore, be concluded that soil amended with organic fertilizers such as compost, and in particular vermicompost, provides a lower incidence of phytopathogens, especially fungi. Isolated actinomycetes have also shown high potential for the production of bioactive compounds useful in the control of plant diseases.
\end{abstract}

Keywords: soil, compost, vermicompost, Streptomyces, natural biofungicide

\section{INTRODUCTION}

Actinomycetes present in soil, play major roles in the cycling of organic matter; they inhibit the growth of several plant pathogens in the rhizosphere and decompose complex mixtures of polymers in dead plant, animal and fungal material, resulting in the production of many extracellular enzymes which are conducive to crop production (Bhatti et al., 2017; Charousová et al., 2016a; Charousová et al., 2017). Soil is constantly one of the most frequent sources of actinomycete-producing new natural bioactive substances (Katz and Baltz, 2016). In agriculture, from actinomycetes the genus Streptomyces plays important roles in increasing soil fertility, degrading organic matter and controlling pathogens. In the arable soil, amended with compost or vermicompost are often present actinomycetes (non-pathogenic), capable of producing various secondary metabolites and bioactive substances to reduce plant disease (Kinkel et al., 2012; Suárez-Estrella et al., 2013; Charousová et al., 2016b). At present, Streptomyces sp. for biocontrol against bacterial, fungal, oomycete, viral and nematode pathogens remain an active target for biocontrol research, and many promising Streptomyces strains have been evaluated for efficacy and patented (Clermont et al., 2011; El Karkouri et al., 2010; Faheem et al., 2015). An effective method for assessing the presence of these biosynthetic pathways is the detection of polyketide synthases (PKS) and nonribosomal peptide synthetases (NRPS) genes by PCR. NRPS and PKS are biosynthetic systems involved in the synthesis of a large number of important biologically active compounds produced by microorganisms, among others by actinomycetes. NRPS and PKS participate in the production of secondary metabolites like antibiotics, siderophores, pigments, antihelmintics, antifungals, antitumor agents and immunosuppressives (Ayuso-Sacido and Genilloud, 2005; Gartemann et al., 2003). Structurally, both PKS-I and NRPS are multifunctional polypeptides encoded by a variable number of modules with multiple enzymatic activities. Each PKS-I module encodes at least three domains corresponding to a ketosynthase (KS), acyltransferase (AT), and acyl carrier protein (ACP) involved in the selection and condensation of the correct extender unit. They can also include additional enoylreductase, dehydratase, and ketoreductase activities involved in the reduction of the $\beta$-keto group formed in the condensation (Ayuso-Sacido and Genilloud, 2005).

In this study, we wanted to confirm our hypothesis that the addition of organic fertilizers to the soil, such as composts and especially vermicomposts, may increase the incidence of actinomycetes with antifungal activities, in particular by producing a wide range of bioactive metabolites. Antifungal activity and overall bioactive potential of actinomycetes isolates were evaluated not only by in vitro antagonism assay, but also by PCR amplification of specific sequences of genes encoding NRPS and PKS type I and II (PKS-I, PKS-II).

\section{MATERIAL AND METHODS}

\section{Sample collection}

Actinomycetes were isolated from soil (Haplic Fluvisol) located near Nitra (Slovakia - latitude $48^{\circ} 31^{\prime} 35.97^{\prime \prime} \mathrm{N}$, longitude 18 11' 46.82" E), one compost, one vermicompost and soil amended with compost or vermicompost. Vermicompost and compost were applied to the soil at a total dose of $20 \mathrm{Mg} \cdot \mathrm{ha}^{-1}$ The applied compost was prepared by mixing straw ( $11 \%$ by dry weight $-\mathrm{dw})$, hay ( $3 \%$ by $\mathrm{dw}$ ), silage ( $32 \%$ by $\mathrm{dw}$ ), sheep manure ( $9 \%$ by $\mathrm{dw})$, cow manure (34\% by $\mathrm{dw}$ ) and soil from the subsoil (11\% by $\mathrm{dw})$. Vermicompost was prepared by mixing the compost ( $41 \%$ by $\mathrm{dw})$, cow manure ( $20 \%$ by $\mathrm{dw})$, peat and forest litter $(21 \%$ by dw), soil ( $10 \%$ by dw), a compound of grass, straw and hay $(6 \%$ by $\mathrm{dw})$ and the fill vermin $(2 \%$ by $\mathrm{dw})$. The fill vermin (older vermicompost) containing earthworms and cocoons of earthworms (70 earthworms $\mathrm{dm}^{-3}$ ) was added to the compost. The basic chemical and microbial characteristics of soil samples and both composts (Table 1) were determined according to the defined values: oxidizable carbon $\left(\mathrm{C}_{\mathrm{ox}}\right)$ by the Tiurin method, total nitrogen $\left(\mathrm{N}_{\mathrm{t}}\right)$ by the Kjeldahl distillation method, $\mathrm{pH}\left(\mathrm{H}_{2} \mathrm{O}\right)$ and microbial biomass carbon $\left(\mathrm{C}_{\text {mic }}\right)$, which was determined by the fumigation-extraction method of Vance et al. (1987). 
Table 1 Basic characteristics of soil, compost/vermicompost and soil with compost/vermicompost.

\begin{tabular}{|c|c|c|c|c|c|c|}
\hline Characteristic & Unit & $S$ & $\mathrm{C}$ & $\mathrm{V}$ & $\mathrm{S}+\mathrm{V}$ & $\mathrm{S}+\mathrm{C}$ \\
\hline $\mathrm{C}_{\text {mic }}$ & $\mu \mathrm{g} \cdot \mathrm{g}^{-1}{ }_{\text {d.w.s. }}$ & 461.84 & 756.06 & 931.81 & 585.37 & 547.08 \\
\hline $\mathrm{N}_{\mathrm{t}}$ & $\%$ & 0.16 & 1.19 & 1.7 & 0.17 & 0.21 \\
\hline$C_{o x}$ & $\%$ & 1.2 & 9.93 & 13.26 & 1.43 & 1.28 \\
\hline $\mathrm{pH}_{(\mathrm{H} 2 \mathrm{O})}$ & & 6.42 & 8.64 & 7.65 & 6.92 & 6.62 \\
\hline
\end{tabular}

Isolation, and morphological characterization of actinomycetes

Microbial analysis was performed always within $24 \mathrm{~h}$ of sampling. At first, actinomycete colonies were cultivated on Pochon medium (GrabińskaLoniewska, 1999) using the conventional dilution plate procedure, while 10-fold dilutions of the suspensions were prepared down to $10^{-4}$ from $1 \mathrm{~g}$ of fresh soil and sterile saline solution. Samples were cultivated from 5 to 7 days at $28^{\circ} \mathrm{C}$ in a cultivation box. After cultivation the numbers putative actinomycete colonies were expressed in colony-forming units (CFU) per $1 \mathrm{~g}$ of dry matter. The International Streptomyces Project (ISP) (Shirling and Gottlieb, 1966) was used to choose isolates belonging to the Streptomyces genus. Dry, powdered colonies showing features of streptomycetes were purified from Pochon medium on ISP2 medium that is declared according to ISP as a standard culture medium for morphological studies. The basic morphological characteristics of streptomycetes include the colour of the sporulating aerial mycelium, the colour of the substrate mycelium, the colour of diffusible soluble pigments, and spore morphology. The experiment to determine potential for melanin production was performed on ISP6 medium (peptone yeast extract iron agar). Evaluation of melanin production was performed after 4 days. Cultures forming a greenish brown to brown to black diffusible pigment were recorded as positive.

\section{Molecular identification of actinomycetes}

Genetically characterized according to $16 \mathrm{~S}$ rRNA sequencing were 22 morphologically different isolates of actinomycetes. The isolation of total DNA was performed according to Sambrook and Russell (2000). For PCR amplification of specific 16S rRNA sequences of streptomycetes, the following set of primers were used: F1 (5'-AGAGTTTGATCITGGCTCAG-3'; I=inosine) and R1 (5'-ACGGITACCTTGTTACGACTT-3') (Cook and Meyers, 2003) The total volume of PCR reaction solution was $50 \mu 1$, with the following composition: $2 \mu \mathrm{l}$ template DNA (approximately $20 \mathrm{ng}$ ); $1 \times$ PCR buffer with $\mathrm{KCl} ; 0.2 \mathrm{mmol} . \mathrm{dm}^{-3} \mathrm{dNTP} ; 1.5 \mathrm{mmol} . \mathrm{dm}^{-3} \mathrm{MgCl}_{2} ; 0.5 \mu$ mol.dm ${ }^{-3}$ of each primer, and $30 \mathrm{U} \cdot \mathrm{ml}^{-1}$ DreamTaq ${ }^{\mathrm{TM}}$ polymerase (Fermentas). Amplification was run in a thermocycler (Biometra TPersonal) in the following steps: denaturation at $95{ }^{\circ} \mathrm{C}$ for $3 \mathrm{~min} ; 45$ cycles with the following profiles: denaturation at $95{ }^{\circ} \mathrm{C}$ for $30 \mathrm{~s}$, annealing at $56^{\circ} \mathrm{C}$ for $30 \mathrm{~s}$ and polymerization at $72{ }^{\circ} \mathrm{C}$ for $90 \mathrm{~s}$; and final polymerization at $72{ }^{\circ} \mathrm{C}$ for $5 \mathrm{~min}$ and cooling to $4{ }^{\circ} \mathrm{C}$. The quality and quantity of amplified PCR product were determined by electrophoresis on $1 \%$ agarose gel at a voltage of $10 \mathrm{~V} \cdot \mathrm{cm}^{-1}$ for $20 \mathrm{~min}$. The enzymatically purified amplified fragments were sequenced using F1 primer by MacroGen (South Korea). The similarity of the $16 \mathrm{~S}$ rRNA gene sequences to the sequences of type strains in the GenBank database was performed using the Basic Alignment Search Tool (BLAST). Sequences were aligned using the MUSCLE algorithm (Edgar, 2004). A phylogenetic tree was constructed by the maximum likelihood (ML) method based on the General Time Reversible model in MEGA6 software (Tamura et al., 2013) with partial deletion of gaps and a BioNJ starting tree. ML analysis was followed by 10000 bootstrap replications.

\section{Antifungal activity of actinomycetes}

Antifungal activity of selected isolates was determined using the agar blocks method (Nedialkova and Naidenova, 2005). In total, we tested eight phytopathogenic species of fungi from the Microorganisms Collection at the Slovak University of Agriculture in Nitra: Alternaria arborescens (KMi-15H6ZM; source: Solanum lycopersicum); Alternaria tenuissima (KMi-16A6-ZM source: Fragaria ananassa); Aspergillus niger (KMi-0146-LR; source: Vitis vinifera); Botrytis cinerea (KMi-29B11-ZM; source: Fragaria ananassa); Fusarium poae (KMi-12A18-ZM; source: Triticum aestivum); Penicillium expansum (KMi-306-LR; source: Malus domestica); Rhizoctonia solani (KMi003-JM; source: Solanum esculentum) and Sclerotinia sclerotiorum (KMi-001JM; source: Helianthus annuus). Microscopic fungi were cultivated on malt extract agar (Merck \& Co.). Agar blocks of the streptomycetes with a diameter of $9 \mathrm{~mm}$ were placed on the surface of the solid medium with inoculated fungi. The blocks of streptomycetes were cut out from well-grown cultures cultivated on ISP2 medium at $30{ }^{\circ} \mathrm{C}$ for 6 to 10 days. Petri dishes with inoculums of tested fungi were incubated for $72 \mathrm{~h}$ at $25{ }^{\circ} \mathrm{C}$. All experiments were carried out in duplicate. The results were evaluated by measuring the diameter of the inhibition zone in mm with a Haloes Caliper (IUL Instruments). The sizes of inhibition zones are listed as the diameter of the clear zone in $\mathrm{mm}$ including the diameter of agar blocks $(9 \mathrm{~mm})$. Antagonism was determined by measuring the distance between the growing edges of actinomycetes and fungi, hence establishing four levels of inhibition: maximum scored as an inhibition distance $>20 \mathrm{~mm}$, intermediate as a distance of 10-20 mm, minimum as a measurement $<10 \mathrm{~mm}$ and no antagonism (-) when contact between actinomycetes and fungi did not occur. We considered antifungal activity of isolates important if the inhibitory zone value was equal to or greater than $20 \mathrm{~mm}$.

\section{Detection of genes encoding NRPS and PKS}

The presence of genes for NRPS and PKS that are considered as indicators of bioactive potential was proven using the PCR method on DNA isolated from individual isolates with the gene specific primers. Several sets of primers joining to different sequences of genes were used (Table 2).

The PCR products were amplified in $50 \mu$ l solution containing: $5 \mu$ l template DNA (approximately $20 \mathrm{ng}$ ); $1 \times$ PCR buffer with $\mathrm{KCl} ; 0.2$ mmol.dm $^{-3} \mathrm{dNTP}$ $1.5 \mu \mathrm{mmol} . \mathrm{dm}^{-3} \mathrm{MgCl}_{2} ; 0.4 \mu \mathrm{mol} . \mathrm{dm}^{-3}$ of each primer, and $30 \mathrm{U} \cdot \mathrm{ml}^{-}$ DreamTaq $^{\mathrm{TM}}$ polymerase (Fermentas). The program for NRPS amplification included denaturation at $95{ }^{\circ} \mathrm{C}$ for $3 \mathrm{~min}$; followed by 40 cycles at $95{ }^{\circ} \mathrm{C}$ for $30 \mathrm{~s}$, $53{ }^{\circ} \mathrm{C}$ for $30 \mathrm{~s} 72{ }^{\circ} \mathrm{C}$ for $30 \mathrm{~s}$; and final elongation step of $5 \mathrm{~min}$ at $72{ }^{\circ} \mathrm{C}$. The amplification of PKS was run in following steps: denaturation at $95^{\circ} \mathrm{C}$ for $3 \mathrm{~min}$; 40 cycles at $95{ }^{\circ} \mathrm{C}$ for $30 \mathrm{~s}, 56{ }^{\circ} \mathrm{C}$ for $30 \mathrm{~s}, \quad 72{ }^{\circ} \mathrm{C}$ for $90 \mathrm{~s}$; and final polymerization at $72{ }^{\circ} \mathrm{C}$ for $10 \mathrm{~min}$. PCR products were visualized in a Gel Logic 212 (Carestream Health, Inc., USA) and compared to the expected size (Table 2).

Table 2 PCR primers for screening the biosynthetic genes.

\begin{tabular}{|c|c|c|c|c|}
\hline Gene name & $\begin{array}{l}\text { Primer } \\
\text { labels }\end{array}$ & Sequences $5^{\prime}-3^{\prime}$ & References & $\begin{array}{c}\text { Product size } \\
\text { (bp) }\end{array}$ \\
\hline NRPS & $\begin{array}{l}\text { A3F } \\
\text { A7R }\end{array}$ & $\begin{array}{l}\text { GCSTACSYSATSTACACSTCSGG } \\
\text { SASGTCVCCSGTSCGGTAS }\end{array}$ & Ayuso-Sacido \& Genilloud, 2005 & $700-800$ \\
\hline PKS-I $_{1}$ & $\begin{array}{l}\text { K1F } \\
\text { M6R }\end{array}$ & $\begin{array}{l}\text { TSAAGTCSAACATCGGBCA } \\
\text { CGCAGGTTSCSGTACCAGTA }\end{array}$ & Ayuso-Sacido \& Genilloud, 2005 & $1200-1400$ \\
\hline PKS-I 2 & $\begin{array}{l}\text { PKS-I-A } \\
\text { PKS-I-B }\end{array}$ & $\begin{array}{l}\text { GCSATGGAYCCSCARCARCGSVT } \\
\text { GTSCCSGTSCCRTGSSCYTCSAC }\end{array}$ & Schirmer et al., 2005 & 700 \\
\hline PKS-IKS-domain & $\begin{array}{l}\text { KSLF } \\
\text { PKS-I-B }\end{array}$ & $\begin{array}{l}\text { CCSCAGSAGCGCSTSYTSCTSGA } \\
\text { GTSCCSGTSCCRTGSSCYTCSAC }\end{array}$ & Ginolhac et al., 2004 & 700 \\
\hline PKS-II ${ }_{K S \alpha}$ & $\begin{array}{l}\mathrm{KS} \alpha \mathrm{F} \\
\mathrm{KS} \alpha \mathrm{R}\end{array}$ & $\begin{array}{l}\text { TSGCSTGCTTGGAYGCSATC } \\
\text { TGGAANCCGCCGAABCCGCT }\end{array}$ & Metsä-Ketelä et al., 1999 & 613 \\
\hline
\end{tabular}

\section{RESULTS AND DISCUSSION}

Impact of adding compost or vermicompost on actinomycete numbers and morphological characteristics of actinomycete isolates

Soil microbial carbon $\left(\mathrm{C}_{\text {mic }}\right)$ values indicated an increased presence of microorganisms in the soil after the addition of compost and, in particular, vermicompost. Assigned numbers of actinomycetes in soil with or without compost/vermicompost (Table 3), confirming numbers with an order of magnitude of $10^{4} \mathrm{CFU} . \mathrm{g}^{-1}$ d.w.s., are comparable with values that were determined using the conventional dilution method in tropical soils (Semêdo et al., 2001). We determined values about 100 times lower than those reported by Himaman $\boldsymbol{e}$ al. (2016), who isolated actinomycetes from the area of the soil rhizosphere. The lowest number of actinomycetes was recorded in the soil without the addition of composts; the addition of both composts increased the number of actinomycetes compared to that in untreated soil, especially in the case of vermicompost application, by up to 12 times. In total, 352 actinomycete isolates were successfully recovered from soil using on Pochon medium. Twenty-two isolates were from the soil without the addition of composts, 21 isolates were from 
compost and vermicompost, 142 isolates were from compost-amended soil, and 146 were from vermicompost-amended soil (Table 3). Next, we focused on detailed characterisation of 22 mycelium-forming colonies that were selected from all isolates based on the similarity of macroscopically observable typical morphological characteristics (colour, appearance, smell).

Table 3 Number, total number of actinomycetes obtained on ISP2 medium and number of selected-actinomycete isolates for further genetic characterisation

\begin{tabular}{|c|c|c|c|c|c|c|}
\hline Characteristic & Unit & $\mathrm{S}$ & $\mathrm{C}$ & $\mathrm{V}$ & $\mathrm{S}+\mathrm{V}$ & $\mathrm{S}+\mathrm{C}$ \\
\hline $\begin{array}{l}\text { Number } \\
\text { of actinomycetes }\end{array}$ & & 6.91 & 45.72 & 41.39 & 87.13 & 48.24 \\
\hline $\begin{array}{l}\text { Total number of } \\
\text { isolates on ISP2 medium }\end{array}$ & $10^{4} \mathrm{CFU} \cdot \mathrm{g}^{-1}$ d.w.s. & 22 & 21 & 21 & 146 & 142 \\
\hline $\begin{array}{l}\text { Selected tested } \\
\text { actinomycete isolates }\end{array}$ & & 6 & 2 & 2 & 9 & 3 \\
\hline
\end{tabular}

$\mathrm{S}$ - soil; C - compost; $\mathrm{V}$ - vermicompost; d.w.s. - dry weight of soil; CFU - colony-forming units.

Based on the results of Gram staining and evaluation of other morphological properties of colonies, we assumed that they were representatives of the genus Streptomyces (Table 4). The dominant colour of aerial mycelium was grey in isolates from soil and white in isolates from soil amended with vermicompost. A red colour was present only in compost isolates or soil amended with compost. Barakate et al. (2002) reported that isolates with yellow air mycelium are the most active against microscopic fungi and yeastsIn this study, only one isolate from compost, 77VY13, had yellow airborne mycelium, however, it was able the suppress the growth $(\geq 20 \mathrm{~mm})$ only of one of tested phytopahogens (Rhizoctonia solani). Evaluation of the substrate mycelium resulted in our isolates belonging to the colour group yellow-brown. The genus Streptomyces is known to produce many types of pigments with different biological effects. Among isolates, only one was colourless. Isolates from compost/vermicompost did not produce any pigmenton ISP2 medium. All observed morphological properties were also used to identify isolates themselves in fusion with the results of the observed genetic characteristics of the individual isolates.

Table 4 Identification of actinomycete isolates using genetic and morphological characteristics.

\begin{tabular}{|c|c|c|c|c|c|c|c|c|c|}
\hline Isolate & Closest match & Accession number & Similarity & $\begin{array}{c}\text { Colour of } \\
\text { aerial mycelium }\end{array}$ & $\begin{array}{l}\text { Colour of substrate } \\
\text { mycelium }\end{array}$ & $\begin{array}{l}\text { Pigment colour } \\
\text { ISP2 }\end{array}$ & $\begin{array}{c}\text { Shape of } \\
\text { sporophore }\end{array}$ & $\begin{array}{c}\text { Melanoid } \\
\text { pigment } \\
\text { ISP6 }\end{array}$ & $\begin{array}{l}\text { Gram } \\
\text { staining }\end{array}$ \\
\hline \multicolumn{10}{|c|}{ Soil with vermicompost } \\
\hline $12 \mathrm{VK} 13$ & S. flavovariabilis & KF317953 & $99 \%$ & White & Bottle green & - & $\mathrm{RF}$ & - & + \\
\hline $51 \mathrm{VK} 13$ & S. sampsonii & KР096298 & $99 \%$ & Beige & Brown-beige & - & $\mathrm{RF}$ & - & + \\
\hline $101 \mathrm{~K} 14$ & S. pulveraceus & KM370063 & $99 \%$ & Grey & Yellow-brown & Brown & $\mathrm{RF}$ & - & + \\
\hline $104 \mathrm{~K} 14$ & S. melanogenes & EF620358 & $99 \%$ & White & Yellow-brown & Brown & $\mathrm{R}$ & + & + \\
\hline $244 \mathrm{~K} 14$ & S. spiroverticillatus & KJ531630 & $99 \%$ & White & Yellow-brown & - & RA & + & + \\
\hline \multicolumn{10}{|c|}{ Vermicompost } \\
\hline $167 \mathrm{~K} 14$ & S. tanashiensis & GU350491 & $99 \%$ & Grey & Ochre & - & $\mathrm{RF}$ & - & + \\
\hline $170 \mathrm{~K} 14$ & S. globisporus & KJ155505 & $99 \%$ & Cream & Brown-beige & - & $\mathrm{RF}$ & - & + \\
\hline \multicolumn{10}{|c|}{ Soil with compost } \\
\hline 27VY14 & S. avidinii & KF620323 & $99 \%$ & Grey & Yellow-brown & - & RA & + & + \\
\hline 34VY14 & S. yokosukanensis & KF620289 & $99 \%$ & Colourless & Sand yellow & - & $\mathrm{S}$ & - & + \\
\hline \multicolumn{10}{|c|}{ Soil } \\
\hline $6 \mathrm{~K} 14$ & S. griseoruber & FJ919750 & $100 \%$ & Grey & Red & - & $\mathrm{RF}$ & + & + \\
\hline 16VY13 & S. olivochromogenes & KJ767381 & $100 \%$ & Colourless & Brown-beige & - & $\mathrm{RF}$ & - & + \\
\hline 30VY13 & S. mirabilis & FK-749 & $99 \%$ & Grey & Yellow-brown & Brown & RA & + & + \\
\hline 69VY13 & S. exfoliates & LN774748 & $99 \%$ & Grey & Yellow-brown & Yellow & $\mathrm{RF}$ & - & + \\
\hline 69VY14 & S. atratus & LK021136 & $99 \%$ & Beige & Yellow-brown & - & $\mathrm{S}$ & - & + \\
\hline $186 \mathrm{~K} 14$ & S. collinus & NR041063 & $100 \%$ & Cream & Dahlia yellow & - & $\mathrm{RF}$ & + & + \\
\hline
\end{tabular}

$\mathrm{R}$ - rectus; $\mathrm{RF}$ - rectus flexibilis; $\mathrm{RA}$ - retinaculum apertum; $\mathrm{S}$ - spira; (+) pigment production observed; (-) without production of pigment

The acquired sequences of $16 \mathrm{~S}$ rRNA gene were compared with sequences of type species (bacterio.net) from the GenBank database using BLAST. Affiliation of our isolates to the genus Streptomyces was confirmed, while there were identified 22 different strains of Streptomyces with $98 \%$ to $100 \%$ similarity to type species (Table 4). Phylogenetic analysis of 22 isolates and the 36 most similar type species of Streptomyces resulted in the dendrogram shown in Fig. 1 There are 10 well-defined clusters, and the majority of strains are clustered with type species. Some strains - 104K14, 12VK13, 244K14, 34V14 and 51VK13were not clustered with the most similar type species. Clustering did not show any similarity between isolates in regard to their isolation source. The genus Streptomyces comprises around 850 described species, and this number is constantly increasing. Moreover, identification of streptomycetes using $16 \mathrm{~S}$ rRNA sequences is complicated as morphologically different species can share the same sequence, while the variability of sequences within single species is common. A polyphasic system of identification which also uses morphological properties must be used for proper identification. Thus, some of our isolates may be reclassified after description of new species.
The effect of organic fertilization on antifungal activity of isolated streptomycetes

From the 22 isolates tested, isolate 51VK13 (S. sampsonii), 12VK13 ( $S$ flavovariabilis) and $170 \mathrm{~K} 14$ (S. globisporus) were the most active. All these isolates were from soil with the addition of vermicompost or vermicompost alone (Table 5). Isolate 51VK13 (S. sampsonii) inhibited the all phytopathogenic fungi tested (100\%), especially Alternaria tenuissima $(44 \mathrm{~mm})$ and Sclerotinia sclerotiorum $(40 \mathrm{~mm}$ ). Isolate $12 \mathrm{VK} 13$ (S. flavovariabilis) was bioactive with all phytopathogens tested except Fusarium poae and isolate $170 \mathrm{~K} 14$ (S globisporus) the most prominently ( $\geq 20 \mathrm{~mm}$ ) inhibited the growth of another six phytopathogens. The most antagonistic relationship was observed agains Penicillium expansum $(34 \mathrm{~mm})$. S. melanogenes inhibited the growth $(\geq 20 \mathrm{~mm})$ of more than half of the phytopathogenic fungi tested. $S$. melanogenes produces only melanomycin with antitumor effects; a phytopathogenic use has not yet been published. Another 14 isolates inhibited less than half of the tested phytopathogenic fungi and no significant inhibitory activity was found in 4 streptomycete isolates. 


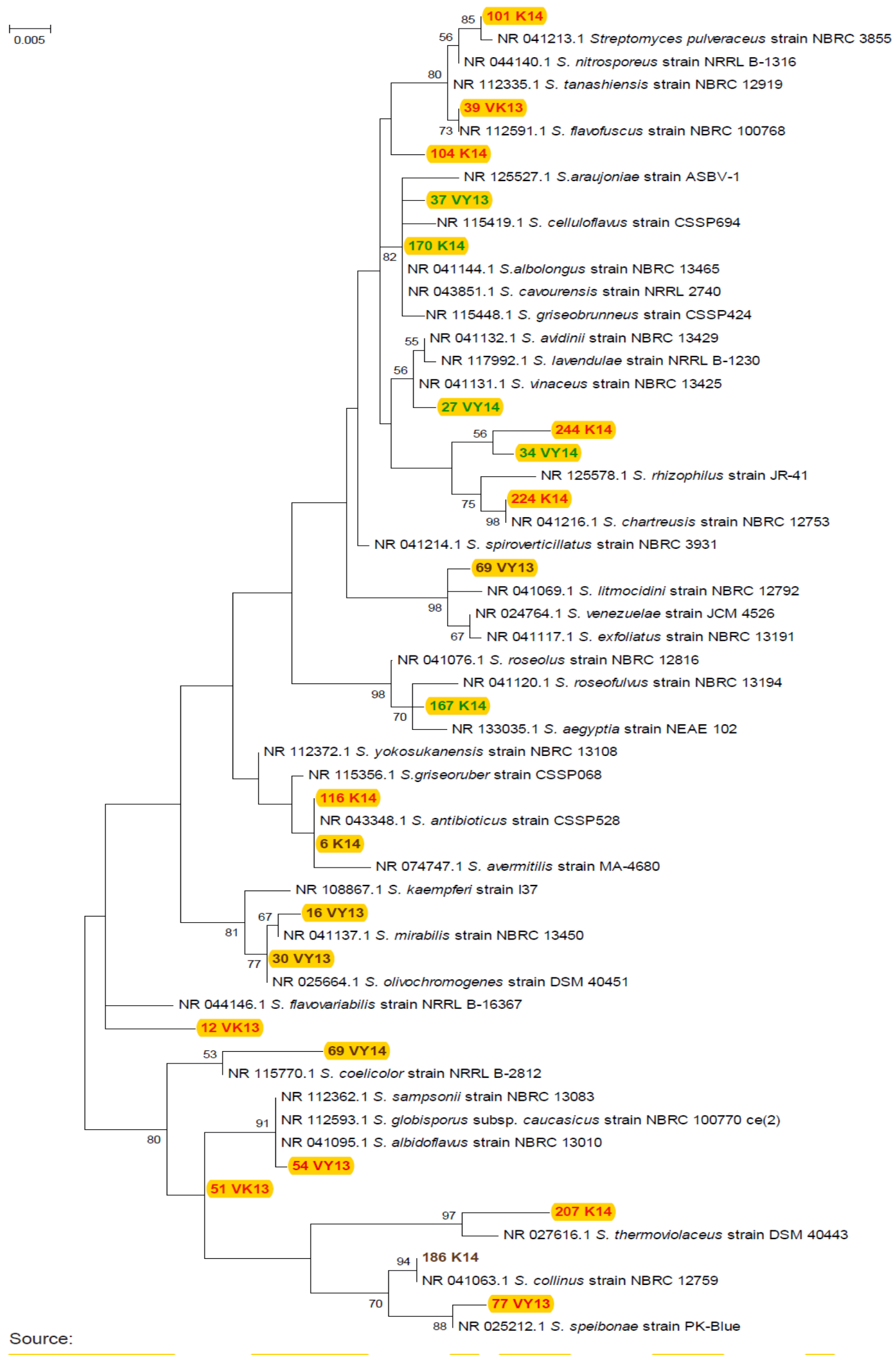

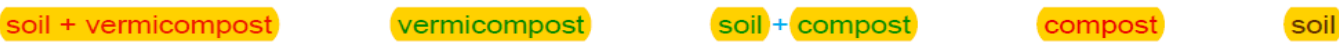

Figure 1 Phylogenetic dendrogram obtained by neighbour-joining analysis based on 16S rRNA gene sequences. Bootstrap numbers higher than $50 \%$ are presented. The scale bar represents 0.005 changes per nucleotide.

The most significant activity $(45 \mathrm{~mm})$ of $12 \mathrm{VK} 13$ (S. flavovariabilis) isolate from soil amended with vermicompost was found against Sclerotinium sclerotiorum. Baniasadi et al. (2009) found inhibition of S. sclerotiorum by only $20 \%$ of actinomycetes isolated from soil. Li et al. (2012) found strong inhibition of S. sclerotiorum by the actinomycete strain Streptomyces globisporus JK-1, our isolate 170K14 (S. globisporus) had weaker activity $(14 \mathrm{~mm})$. Sclerotinia sclerotiorum is an economically important necrotrophic fungal pathogen with a worldwide distribution of more than 400 dicotyledonous host species (Kirk et al.
2001). The ability of S. sclerotiorum to infect different plant species and tissues under a wide range of environmental conditions, as well as its ability to produce sclerotia that survive in the soil for many years, contribute to the persistent and widespread nature of this pathogen (Bolton et al., 2005). Achieving good control of Sclerotinia blight is difficult and a challenge in all crops. Management of the disease requires the use of a wide range of strategies. Fungicide application can decrease the disease incidence and increase the yield, on both susceptible and resistant cultivars (Woodward et al., 2015). Biological control with antagonistic 
fungi (Coniothyrium minitans, Trichoderma spp.), has been reported, however, efficacy of these mycoparasites is not consistent in the field. In contrast, a number of bacterial species, such as Pseudomonas, Bacillus and Streptomyces confirmed potential antagonism against S. sclerotiorum (Cheng et al., 2014; Kamal et al., 2016). Therefore, biocontrol agents based on streptomyces could pave the way for sustainable management of S. sclerotiorum.

The activity of isolates from soil, compost and soil amended with compost was lower compared to that of isolates from vermicompost and soil amended with vermicompost. Important antifungal activity was observed only in isolates from soil without the addition of compost 16VY13 (S. olivochromogenes) against
Aspergillus niger $(40 \mathrm{~mm})$ and isolate from soil 186K14 (S. collinus) against Rhizoctonia solani $(36 \mathrm{~mm})$. Aspergillosis caused by the species Aspergillus fumigatus, A. flavus, A. terreus and A. niger is among the most frequent opportunistic fungal infections (Ayari, 2012). Basavaraj et al. (2010) detected activity against $A$. niger only in $33 \%$ of streptomycete isolates from soils, and Thakur et al. (2007) in $31.91 \%$ of soil actinomycetes. From the 22 of our tested isolates, only $31.8 \%$ showed the important inhibited activity $(\geq 20 \mathrm{~mm})$ against A.niger.

Table 5 Antifungal activity of streptomycete isolates according to the size of inhibition zones in $\mathrm{mm}$

Isolate/Taxon

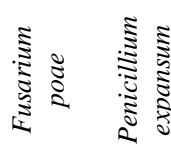

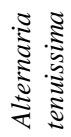
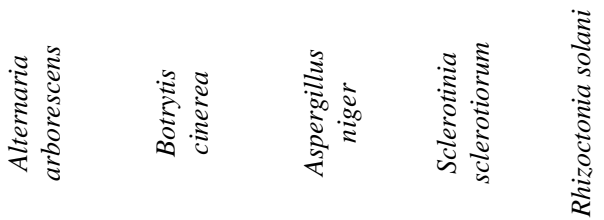

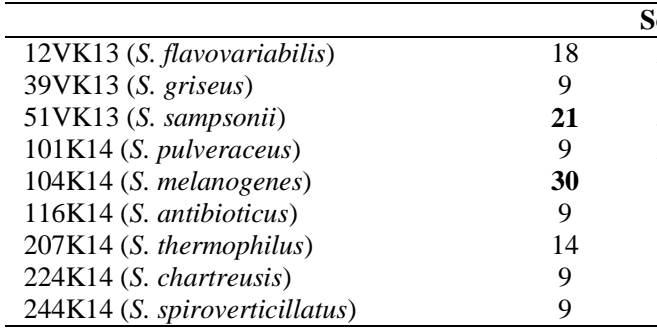

\section{Soil with vermicompos}

9036

30

21

17

9

18

12

167K14 (S. tanashiensis) 9

\begin{tabular}{|c|c|c|c|c|c|c|c|c|}
\hline \multicolumn{9}{|c|}{ Soil with compost } \\
\hline 27VY14 (S avidinii) & 9 & 13 & 18 & 14 & 13 & 9 & 19 & 20 \\
\hline 34VY14 (S. yokosukanensis) & 22 & 18 & 20 & 26 & 16 & 22 & 9 & 9 \\
\hline 37VY13 (S. puniceus) & 9 & 11 & 9 & 17 & 12 & 9 & 9 & 9 \\
\hline \multicolumn{9}{|c|}{ Compost } \\
\hline 54VY13 (S. albidoflavus) & 9 & 12 & 12 & 13 & 20 & 9 & 9 & 9 \\
\hline 6K14 (S. griseoruber) & 9 & 9 & 9 & 21 & 17 & 9 & 9 & 24 \\
\hline 16VY13 (S. olivochromogenes) & 15 & 12 & 12 & 9 & 13 & 40 & 26 & 9 \\
\hline 30VY13 (S. mirabilis) & 12 & 18 & 12 & 9 & 13 & 24 & 9 & 18 \\
\hline 69VY13 (S. exfoliatus) & 9 & 9 & 9 & 12 & 11 & 9 & 9 & 14 \\
\hline 69VY14 (S. atratus) & 9 & 28 & 22 & 9 & 20 & 9 & 26 & 9 \\
\hline 186K14 (S. collinus) & 9 & 20 & 9 & 9 & 9 & 9 & 24 & 36 \\
\hline
\end{tabular}

Vermicompost

Note: bold text indicates important activity $(\geq 20 \mathrm{~mm})$.

Assessment of antifungal activity of actinomycete isolates by the presence of genes coding NRPS and PKS

The antagonistic activity of Streptomyces to fungal pathogens is usually related to the production of antifungal compounds, and an effective method for assessing the presence of the biosynthetic pathways for the formation of bioactive metabolites is the detection of PKS and NRPS genes by PCR (HernándezMacedo et al., 2014). The results of this study (Table 6) showed that, the tested isolates with antifungal activity exhibited positive PCR for the presence of PKSII $(86 \%)$, followed by PKS-I2 (77\%), NRPS $(68 \%)$ and PKS-I $\mathrm{I}_{1}(36 \%)$. More frequent occurrence of NRPS than PKS-I biosynthetic pathways in the genome of actinomycetes was observed also by others (Ayuso-Sacido and Genilloud, 2005; Pathom-Aree et al. (2006); Chroňáková et al. 2010), while greater representation of PKS genes was observed in samples isolated from the mineral soil layer.

In the genome of each of our tested isolates was found at least one of the screened sequences for NRPS or PKS. The ability to amplify all tested gene sequences was shown in six streptomycetes, namely 170K14 (S. globisporus), 12 VK13 (S. flavovariabilis), 27VY14 (S. avidinii), 101K14 (S. pulveraceus), $116 \mathrm{~K} 14$ (S. antibioticus) and 224K14 (S. chartreusis). Isolate 186K14 (S. collinus) contains two genes encoding PKS-I (Table 6), and isolate 16VY13 ( $S$. olivochromogenes) did not show the presence of PKS-I by any primer pairs. However, the presence of NRPS and PKS sequences may not always be consistent with the production of substances with secondary metabolism (AyusoSacido and Genilloud, 2005). Antifungal activity may be caused by various secondary metabolites, not necessarily connected to polyketids or non-ribosomal proteins. According our results, antiungal activity was not detected in 4 isolates 116K14 (S. antibioticus), 101K14 (S. pulveraceus), 224K14 (S. chartreusis) a
27VY14 (S. avidinii) which contained all four screened genes. On the other hand isolate 51VK13 (S. sampsonii) showed the high antifungal activity despite no presence of NRPS/PKS.

Macrolides, oligoethers (polyethers) and oligoenes (polyenes) are produced mostly by PKS-I, while aromatic oligoketides are produced by PKS-II (Knirschová et al., 2007). But, as we can see also in our study, it is not possible to include all of them clearly in this way.

According to Sosio et al. (2000), there is the genetical potential for every actinomycete to produce approximately 10 to 20 different secondary metabolites. The chemical properties of these metabolites can be very diverse and they can be used not only in biological control in agriculture but also in other areas of our lives. 
Table 6 Bioactive potential of isolated streptomycetes based on our results and published literature data

\begin{tabular}{|c|c|c|c|c|c|c|c|}
\hline \multirow{2}{*}{ Isolate/Taxon } & \multirow{2}{*}{ NRPS } & \multicolumn{4}{|c|}{ PKS- } & \multirow{2}{*}{$\begin{array}{l}\text { No. of } \\
\text { isolates with } \\
\text { important } \\
\text { antifungal } \\
\text { activity }\end{array}$} & \multirow{2}{*}{$\begin{array}{l}\text { Reported product according to Compendium of Actinobacteria* from } \\
\text { Wink and other references }\end{array}$} \\
\hline & & $\mathrm{I}_{1}$ & $\mathrm{I}_{2}$ & I & II & & \\
\hline 12VK13 (S. flavovariabilis) & + & + & + & + & + & 7 & No data are published \\
\hline 39VK13 (S. griseus) & - & - & - & - & + & 0 & $\begin{array}{l}\text { Streptomycin (El-Shahed et al., 2008); candicidin (Rebollo et al., 1989); } \\
\text { melanin (Endo et al., 2002); mutanolysin (Brönneke and Fiedler, 1994) }\end{array}$ \\
\hline 51VK13 (S. sampsonii) & + & - & + & + & - & 8 & Haptaene antifungal polyene antibiotics (Jain and Jain, 2007) \\
\hline $101 \mathrm{~K} 14$ (S. pulveraceus) & + & + & + & + & + & 1 & $\begin{array}{l}\text { Actitetal (Wink); epiderstatin (Sonoda et al., 1992); fostriecin (Liu et al., } \\
\text { 2013) }\end{array}$ \\
\hline 104K14 (S. melanogenes) & - & - & + & + & + & 5 & Melanomycin (Sugawara and Onuma, 1957) \\
\hline 116K14 (S. antibioticus) & + & + & + & + & + & 1 & $\begin{array}{l}\text { Actinomycin, boromycin, cinerubin, esmeraldine A, furanone, } \\
\text { chlorothicin, indanomycin, nosiheptide, oleandomycin, rubromycin, } \\
\text { clavam (Wink); dactinomycin (Ayuso-Sacido and Genilloud, 2005) }\end{array}$ \\
\hline 207K14 (S. thermophilus) & - & - & + & - & + & 0 & Thermomycin (Schuurmans et al., 1956) \\
\hline 224K14 (S. chartreusis) & + & + & + & + & + & 0 & $\begin{array}{l}\text { Althiomycin, cephalosporin, cezomycin, chartreusin, N- } \\
\text { deacetyltunicamycin (Wink); chartreusin, calcimycin, tunicamycin } \\
\text { (Doroghazi et al., 2011) }\end{array}$ \\
\hline 244K14 (S. spiroverticillatus) & + & - & - & + & + & 2 & Tautomycin (Chen et al., 2010) \\
\hline 167K14 (S. tanashiensis) & + & - & + & + & + & 1 & Luteomycin (Afifi et al., 2012) \\
\hline 170K14 (S. globisporus) & + & + & + & + & + & 6 & $\begin{array}{l}\text { Antibiotic C } 1027 \text { (Wink); chartreusin, calcimycin (Doroghazi et al., } \\
\text { 2011); landomycin (Rebets et al., 2003) }\end{array}$ \\
\hline 27VY14 (S. avidinii) & + & + & + & + & + & 1 & Streptavidin (Müller et al., 2014) \\
\hline 34VY14 (S. yokosukanensis) & + & + & + & - & + & 4 & Nebularin (Konuk et al., 2008) \\
\hline 37VY13 (S. puniceus) & - & - & + & + & + & 0 & $\begin{array}{l}\text { Clazamycin, viomycin (Wink); dinactin, 1-(2,4-dihydroxy- } \\
\text { 6methylphenyl)-ethanone (Hussain et al., 2018) }\end{array}$ \\
\hline 54VY13 (S. albidoflavus) & - & - & + & - & - & 1 & Antimycin $\mathrm{A}_{18}$ (Yan et al., 2010; Charousová et al., 2016c) \\
\hline 77VY13 (S. werraensis) & + & - & - & - & - & 1 & Erythromycin (Sanghvi et al., 2014) \\
\hline 6K14 (S. griseoruber) & + & - & + & + & + & 2 & $\begin{array}{l}\text { Elastatinal, hedamycin (Wink); actinomycin-D (Praveen and Tripathi, } \\
\text { 2009) }\end{array}$ \\
\hline 16VY13 (S. olivochromogenes) & - & - & - & - & + & 2 & $\begin{array}{l}\text { 4-Hydroxy-3-methoxycinnamic (ferulic) acid esterase (Faulds and } \\
\text { Williamson, 1991) }\end{array}$ \\
\hline 30VY13 (S. mirabilis) & - & - & - & - & + & 1 & $\begin{array}{l}\text { Nitroreductase (Yang et al., 2012); di-(2-ethylhexyl) phthalate (El-Sayed, } \\
\text { 2012) }\end{array}$ \\
\hline 69VY13 (S. exfoliatus) & + & - & + & - & + & 0 & $\begin{array}{l}\text { Poly(3-hydroxybutyrate) depolymerase (García-Hidalgo et al., 2012); } \\
\text { leupeptin, trypsin-protease (Kim and Lee, 1996) }\end{array}$ \\
\hline 69VY14 (S. atratus) & + & + & + & - & + & 4 & $\begin{array}{l}\text { Atramycin A, ilamycin (Wink); hydrazidomycin A (Meyer et al., 2013); } \\
\text { rufomycin A and B (Shibata et al., 1962) }\end{array}$ \\
\hline 186K14 (S. collinus) & + & - & + & + & + & 3 & $\begin{array}{l}\text { Ansatrienin } \mathrm{A}_{2} \text {, fumarylcarboxamido-2,3-diaminopropanoylalanine, } \\
\text { mikamycin, alfa-rubromycin (Wink); kirromycin (Pavlidou et al., 2011) }\end{array}$ \\
\hline
\end{tabular}

+ presence of screened gene; - absence of screened gene; S - Streptomyces; *https://www.dsmz.de/bacterial diversity/compendium-of-actinobacteria.html

\section{CONCLUSION}

We present the results of testing 22 different streptomycetes isolated from soil, compost, vermicompost and soil with the addition of compost or vermicompost. From 11 tested streptomycetes isolated from soil amended with vermicompost and vermicompost, we confirmed important antifungal activity ( $\geq 20 \mathrm{~mm}$ ) against eight phytopathogenic fungi in $35.2 \%$ of cases. Three of them, 51 VK13 $(S$. sampsonii), 12VK13 (S. flavovariabilis) and 170K14 (S. globisporus) confirmed high antifungal activity and other bioactive potential, based on evaluation of the presence of NRPS and PKS genes. Of the isolates tested, the most active, 170K14 (S. flavovariabilis), has antifungal activity with the possibility of further use as a natural biofungicide in crop production.

Acknowledgments: This study was supported by the Scientific Grant Agency of the Ministry of Education, Science, Research and Sport of the Slovak Republic (project Vega no. 1/0305/17) and Science and Research Agency (project APVV no. 15-0543).

\section{REFERENCES}

Afifi, M.M., Atta, H.M., Elshanawan, A.A., Abdoul-Rao, U.M., El-Adly, A.M., 2012. Identification of luteomycin like antibiotic produced by Streptomyces tanashiensis AZ-C442 isolated from Luxor Governorate at Upper Egypt. Microbiol. J. 2 (1), 1-22. http://dx.doi.org/10.3923/mj.2012.1.22.

Ayari, A., Morakchi, H., Djamila, K.G., 2012. Identification and antifungal activity of Streptomyces sp. S72 isolated from Lake Oubeira sediments in NorthEast of Algeria. African Journal of Biotechnology 11 (2), 305-311. http://dx.doi.org/10.5897/ajb10.2345.

Ayuso-Sacido, A., Genilloud, O., 2005. New PCR primers for the screening of NRPS and PKS-I systems in actinomycetes: detection and distribution of these biosynthetic gene sequences in major taxonomic groups. Microb. Ecol. 49 (1), 10-24. http://dx.doi.org/10.1007/s00248-004-0249-6.

Baniasadi, F., Bonjar, G.H.S., Baghizadeh, A., Nik, A.K., Jorjandi, M., Aghighi, S., Farokhi, P.R., 2009. Biological control of Sclerotinia sclerotiorum, causal agent of sunflower head and stem rot disease, by use of soil borne actinomycetes isolates. Am. J. Agric. Biol. Sci. 4 (2), 146-151. http://dx.doi.org/10.3844/ajabssp.2009.146.151.

Barakate, M., Ouhdouch, Y., Oufdou, K., Beaulieu, C., 2002. Characterization of rhizospheric soil streptomycetes from Moroccan habitats and their antimicrobial activities. World J. Microbiol. Biotechnol. 18 (1), 49-54. http://dx.doi.org/10.1023/a:1013966407890.

Basavaraj, K., Chandrashekhara, S., Shamarez, A., Goudanavar, P., Manvi, F., 2010. Isolation and morphological characterization of antibiotic producing actinomycetes. Trop. J. Pharm. Res. 9 (3), 231-236. http://dx.doi.org/10.4314/tjpr.v9i3.56282.

Bhatti, A.A., Haq, S., Bhat, R.A., 2017. Actinomycetes benefaction role in soil and plant health. Microb. Pathog. 111, 458-467. http://dx.doi.org/10.1016/j.micpath.2017.09.036.

Bolton MD, Thomma BP, Nelson BD. Sclerotinia sclerotiorum (Lib.) de Bary: Biology and molecular traits of a cosmopolitan pathogen. Mol Plant Pathol. 2005;7:1-16. https://doi.org/10.1111/j.1364-3703.2005.00316.x.

Brody, J.R., Kern, S.E., 2004. Sodium boric acid: a Tris-free, cooler conductive medium for DNA electrophoresis. BioTechniques 36 (2), 214-216 http://dx.doi.org/10.2144/04362bm02.

Brönneke, V., Fiedler, F., 1994. Production of bacteriolytic enzymes by Streptomyces globisporus regulated by exogenous bacterial cell walls. Appl. Environ. Microbiol. 60 (3), 785-791.

Charousová, I., Javoreková, S., Medo, J., Schade, R., 2016a. Characteristic of selected soil streptomycetes with antimicrobial potential against phytopathogenic microorganisms. J. Microbiol. Biotech. Food Scien. Online. ISSN 1338-5178, 2016, vol. 5, special 1, s. 64-68, http://doi:10.15414/jmbfs.2016.5.special1.64-68. Charousová, I., Medo, J., Halenárová, E., Maková, J., Javoreková, S., 2016b. Effect of fertilization on biological activity of community of soil streptomycetes. $\begin{array}{lllll}\text { J. Cent. } & \text { Eur. } & \text { Agric. } & 17 & \text { (4), }\end{array}$ http://dx.doi.org/10.5513/JCEA01/17.4.1822.

Charousová, I., Steinmetz, H., Medo, J., Javoreková, S., Wink, J., 2016c. Charact erization of antimycins-producing streptomycete strain VY46 isolated from slov ak soil. Braz. Arch. Biol. Techn. 59(0). http://dx.doi.org/10.1590/1678-4324-201 $\underline{6160274}$. 
Charousová I., Medo J., Halenárová E., Javoreková S., 2017. Antimicrobial and enzymatic activity of actinomycetes isolated from soils of coastal islands. J. Adv. Pharm. Technol. Res. 8, 46-51. http:// dx.doi.org/10.4103/japtr.JAPTR_161_16/28516055.

Chen, X.-L., Xu, Y.-H., Zheng, Y.-G., Shen, Y.-C., 2010. Improvement of tautomycin production in Streptomyces spiroverticillatus by feeding glucose and maleic anhydride. Biotechnol. Bioprocess Eng. 15 (6), 969-974. http://dx.doi.org/10.1007/s12257-010-0087-y.

Chroňáková, A., Krištůfek, V., Tichý, M., Elhottová, D. 2010. Biodiversity of streptomycetes isolated from a succession sequence at a post-mining site and their evidence in Miocene lacustrine sediment. Microbiol. Res., 165 (7), 594 608. http://dx.doi.org/10.1016/j.micres.2009.10.002.

Clermont, N., Lerat, S., Beaulieu, C., 2011. Genome shuffling enhances biocontrol abilities of Streptomyces strains against two potato pathogens. J. Appl Microbiol. $111 \quad$ (3), 671-682. http://dx.doi.org/10.1111/j.13652672.2011.05078.x

Cook, A.E., Meyers. P.R., 2003. Rapid identification of filamentous actinomycetes to the genus level using genus-specific 16S rRNA gene restriction fragment patterns. Int. J. Syst. Evol. Microbiol. 53 (6), 1907-1915 http://dx.doi.org/10.1099/ijs.0.02680-0.

Cuesta, G., García-de-la-Fuente, R., Abad, M., Fornes, F., 2012. Isolation and identification of actinomycetes from a compost-amended soil with potential as biocontrol agents. J. Environ. Manage. 95, 280-284. http://dx.doi.org/10.1016/j.jenvman.2010.11.023.

Doroghazi, J.R., Ju, K.-S., Brown, D.W., Labeda, D.P., Deng, Z., Metcalf, W.W., Price, N.P.J., 2011. Genome sequences of three tunicamycin-producing Streptomyces strains, S. chartreusis NRRL 12338, S. chartreusis NRRL 3882, and S. lysosuperificus ATCC 31396. J. Bacteriol. 193 (24), 7021-7022. http://dx.doi.org/10.1128/jb.06262-11.

Edgar, R.C., 2004. Muscle: multiple sequence alignment with high accuracy and high throughput. Nucleic Acids Res. 32 (5), 1792-1797. http://dx.doi.org/10.1093/nar/gkh340.

El Karkouri, A., El Hassani, F.Z., El Mzibri, M., Benlemlih, M., El Hassouni, M. 2010. Isolation and identification of an actinomycete strain with a biocontro effect on the phytopathogenic Erwinia chrysanthemi 3937VIII responsible for soft rot disease. Ann. Microbiol. 60 (2), 263-268. http://dx.doi.org/10.1007/s13213-010-0036-1.

El-Sayed M.H. 2012. Di-(2-ethylhexyl) phthalate, a major bioactive metabolite with antimicrobial and cytotoxic activity isolated from the culture filtrate of newly isolated soil Streptomyces (Streptomyces mirabilis Strain NSQu-25).

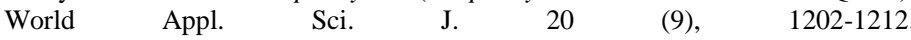
http://dx.doi.org/10.5829/idosi.wasj.2012.20.09.2868.

El-Shahed, K.Y.I., El-Diwany, A., Awad, H.M.M., 2008. Enhanced production of streptomycin and hydrolytic enzymes by Streptomyces griseus strains using different types of organic solvents and detergent compounds. Indian $\mathrm{J}$. Biotechnol. 7 (3), 341-348. http://hdl.handle.net/123456789/1848.

Endo, K., Beppu, T., Hosono, K., Ueda, K., 2002. A novel extracytoplasmic phenol oxidase of Streptomyces: its possible involvement in the onset of $\begin{array}{llll}\text { morphogenesis. } & \text { Microbiology } & 148 & \text { (6), }\end{array}$ http://dx.doi.org/10.1099/00221287-148-6-1767.

Faheem, M., Raza, W., Zhong, W., Nan, Z., Shen, Q., Xu, Y., 2015. Evaluation of the biocontrol potential of Streptomyces goshikiensis YCXU against Fusarium oxysporum f. sp. niveum. Biol. Control 81, 101-110. http://dx.doi.org/10.1016/j.biocontrol.2014.11.012.

Faulds, C.B., Williamson, G., 1991. The purification and characterization of 4 hydroxy-3-methoxycinnamic (ferulic) acid esterase from Streptomyces

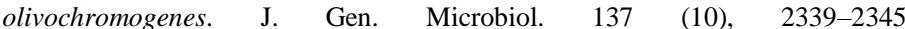
http://dx.doi.org/10.1099/00221287-137-10-2339.

García-Hidalgo, J., Hormigo, D., Prieto, M.A., Arroyo, M., de la Mata, I., 2011 Extracellular production of Streptomyces exfoliatus poly(3-hydroxybutyrate) depolymerase in Rhodococcus sp. T104: determination of optimal biocatalys conditions. Appl. Microbiol. Biotechnol. 93 (5), 1975-1988. http://dx.doi.org/10.1007/s00253-011-3527-5.

Gartemann, K.-H., Kirchner, O., Engemann, J., Gräfen, I., Eichenlaub, R., Burger, A., 2003. Clavibacter michiganensis subsp. michiganensis: first steps in the understanding of virulence of a Gram-positive phytopathogenic bacterium. J Biotechnol. 106 (2-3), 179-191. http://dx.doi.org/10.1016/j.jbiotec.2003.07.011. Ginolhac, A., Jarrin, C., Gillet, B., Robe, P., Pujic, P., Tuphile, K., ... Nalin, R., 2004. Phylogenetic analysis of polyketide synthase I domains from soil metagenomic libraries allows selection of promising clones. Appl. Environ.

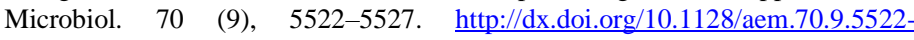
5527.2004.

Grabińska-Łoniewska. A., 1999. Laboratory Exercises in General Microbiology. Oficyna Wydawnicza Politechniki Warszawskiej, Warszawa, 223 pp.

Hernández- Macedo, M., Nunes Barreto, E., de Souza Cavalcanti, A., da Silva, R., dos Anjos Brandão, E., Miranda Fernandes, R., ... Fernandes, M., 2014 Antimicrobial potential of actinomycetes by NRPS and PKS-I pathways. BMC Proc. 8 (Suppl. 4), 175. http://dx.doi.org/10.1186/1753-6561-8-s4-p175.

Himaman, W., Thamchaipenet, A., Pathom-Aree, W., Duangmal, K., 2016 Actinomycetes from Eucalyptus and their biological activities for controlling
Eucalyptus leaf and shoot blight. Microbiol. Res. 188-189, 42-52 http://dx.doi.org/10.1016/j.micres.2016.04.011.

Hussain, A., Rather, M.A., Dar, M.S., Dangroo, N.A., Aga, M.A., Qayum, A., .. Hassan, Q. P., 2018. Streptomyces puniceus strain AS13., production, characterization and evaluation of bioactive metabolites: a new face of dinactin as an antitumor antibiotic. Microbiol. Res. 207, 196-202 http://dx.doi.org/10.1016/j.micres.2017.12.004.

Inbar, E., Green, S.J., Hadar, Y., Minz, D., 2005. Competing factors of compost concentration and proximity to root affect the distribution of streptomycetes. Microb. Ecol. 50 (1), 73-81. http://dx.doi.org/10.1007/s00248-004-0111-x.

Jain, P.K., Jain. P.C., 2007. Isolation, characterization and antifungal activity of Streptomyces sampsonii GS 1322. Indian J. Exp. Biol. 45 (2). 203-206 http://dx.doi.org/nopr.niscair.res.in/handle/123456789/5235.

Katz, L., Baltz, R.H., 2016. Natural product discovery: past, present, and future J. Ind. Microbiol. Biotechnol. 43 (2-3), 155-176 http://dx.doi.org/10.1007/s10295-015-1723-5.

Kim, I.S., Lee, K.J., 1996. Trypsin-like protease of Streptomyces exfoliatus SMF13, a potential agent in mycelial differentiation. Microbiology 142 (7), 1797-1806. http://dx.doi.org/10.1099/13500872-142-7-1797.

Kinkel, L.L., Schlatter, D.C., Bakker, M.G., Arenz, B.E., 2012. Streptomyces competition and co-evolution in relation to plant disease suppression. Res. Microbiol. 163 (8), 490-499. http://dx.doi.org/10.1016/j.resmic.2012.07.005.

Kirk, P.M., Cannon, P., David, J., Stalpers, J., 2001. Ainsworth and Bisby's Dictionary of the Fungi. 9th ed. CABI Publishing; Wallingford, UK: 2001. p. 655

Knirschová, R., Nováková, R., Fecková, L., Timko, J., Turňa, J., Bistáková, J., Kormanec, J., 2007. Multiple regulatory genes in the salinomycin biosynthetic gene cluster of Streptomyces albus CCM 4719. Folia Microbiol. 52 (4), 359-365. http://dx.doi.org/10.1007/bf02932090.

Konuk, M., Ciğerci, I.H., Aksan, S., Korcan, S.E., 2008. Isolation and biochemical characterization of $\delta$-aminolevulinic acid dehydratase from Streptomyces yokosukanensis ATCC 25520. Appl. Biochem. Microbiol. 44 (4), 356-360. http://dx.doi.org/10.1134/s0003683808040030.

Lenc, L., Kwaśna, H., Sadowski, C., 2011. Dynamics of the root/soil pathogens and antagonists in organic and integrated production of potato. Eur. J. Plant Pathol. 131 (4), 603-620. http://dx.doi.org/10.1007/s10658-011-9834-y.

Li, Q., Ning, P., Zheng, L., Huang, J., Li, G., Hsiang, T., 2012. Effects of volatile substances of Streptomyces globisporus JK-1 on control of Botrytis cinerea on tomato fruit. Biol. Control 61 (2), 113-120 http://dx.doi.org/10.1016/j.biocontrol.2011.10.014

Liu, X., Kong, R., Niu, M., Qiu, R., Tang, L. 2013. Identification of the postpolyketide synthase modification enzymes for fostriecin biosynthesis in Streptomyces pulveraceus. J. Natural Products, 76 (4), 524-529. http://dx.doi.org/10.1021/np300667r.

Metsä-Ketelä, M., 1999. An efficient approach for screening minimal PKS genes from Streptomyces. FEMS Microbiol. Lett. 180 (1), 1-6. http://dx.doi.org/10.1016/s0378-1097(99)00453-x.

Meyer, F., Ueberschaar, N., Hertweck, C., 2013. Concise total synthesis of hydrazidomycin A, a rare hydrazide metabolite of Streptomyces atratus. Eur. J Org. Chem 20, 4242-4244. http://dx.doi.org/10.1002/ejoc.201300532.

Müller, J.M., Risse, J.M., Flaschel, E., 2014. Morphological analysis of Streptomyces avidinii in microplates and shake flasks. Chem. Eng. Technol. 86 (9), 1401-1426. http://dx.doi.org/10.1002/cite.201450638.

Nedialkova. D., Naidenova. M., 2005. Screening the antimicrobial activity of actinomycetes strains isolated from Antarctica. J. Cult. Collect. 4 (1), 29-35.

Pathom-Aree, W., Stach, J.E.M., Ward, A.C., Horikoshi, K., Bull, A.T., Goodfellow, M., 2006. Diversity of actinomycetes isolated from Challenger Deep sediment (10,898 m) from the Mariana Trench. Extremophiles 10 (3), 181-189. http://dx.doi.org/10.1007/s00792-005-0482-z.

Pavlidou, M., Pross, E.K., Musiol, E.M., Kulik, A., Wohlleben, W., Weber, T. 2011. The phosphopantetheinyl transferase KirP activates the ACP and PCP domains of the kirromycin NRPS/PKS of Streptomyces collinus Tü 365. FEMS Microbiol. Lett. 319 (1), 26-33. http://dx.doi.org/10.1111/j.15746968.2011.02263.x

Praveen, V., Tripathi, C.K.M., 2009. Studies on the production of actinomycin-D by Streptomyces griseoruber - a novel source. Lett. Appl. Microbiol. 49 (4), 450455. http://dx.doi.org/10.1111/j.1472-765x.2009.02689.x.

Rebollo, A., Gil, J., Liras, P., Asturias, J.A., Martin, J.F., 1989. Cloning an characterization of a phosphate-regulated promoter involved in phosphate contro of candicidin biosynthesis. Gene 9 (1), 47-58. http://dx.doi.org/10.1016/03781119(89)90091-7.

Rebets, Y., Ostash, B., Luzhetskyy, A., Hoffmeister, D., Braňa, A., Mendez, C., Salas, J.A., Berthold, A., Fedorenko, V. 2003. Production of landomycins in Streptomyces globisporus 1912 and S. cyanogenus S136 is regulated by genes encoding putative transcriptional activators. FEMS Microbiol. Lett. 222 (1), 149 153. http://dx.doi.org/10.1016/s0378-1097(03)00258-1

Sambrook, J., Russell, D., 2000. Molecular Cloning: A Laboratory Manual, third ed. (3 volume set). Cold Spring Harbor Laboratory Press, New York, 2344 pp. ISBN 0879695773. 
Sanghvi, G.V., Ghevariya, D., Gosai, S., Langa, R., Dhaduk, N., Kunjadia, P. D., ... Dave, G.S., 2014. Isolation and partial purification of erythromycin from alkaliphilic Streptomyces werraensis isolated from Rajkot, India. Biotechnol. Rep. 1-2, 2-7. http://dx.doi.org/10.1016/j.btre.2014.05.003.

Schirmer, A., Gadkari, R., Reeves, C.D., Ibrahim, F., DeLong, E.F., Hutchinson, C.R., 2005. Metagenomic analysis reveals diverse polyketide synthase gene clusters in microorganisms associated with the marine sponge Discodermia dissoluta. Appl. Environ. Microbiol. $71 \quad$ (8), 4840-4849. http://dx.doi.org/10.1128/aem.71.8.4840-4849.2005.

Schuurmans, D.M., Olson, B.H., San Clemente, C.L., 1956. Production and isolation of thermoviridin, an antibiotic produced by Thermoactinomyces viridis n.sp. Appl. Microbiol. 4 (2), 61-66.

Semêdo, L.T.A.S., Linhares, A.A., Gomes, R.C., Manfio, G.P., Alviano, C.S., Linhares, L.F., Coelho, R.R.R., 2001. Isolation and characterization of actinomycetes from Brazilian tropical soils. Microbiol. Res. 155 (4), 291-299. http://dx.doi.org/10.1016/s0944-5013(01)80007-0.

Shibata, M., Higashide, E., Yamamoto, H., Nakazawa, K., 1962. Studies on streptomycetes. Agric. Biol. Chem. 26 (4), 228-233 http://dx.doi.org/10.1271/bbb1961.26.228.

Shirling, E.B., Gottlieb, D., 1966. Methods for characterization of Streptomyces $\begin{array}{llllll}\text { species. Int. J. } & \text { Syst. } & \text { Bacteriol. } 16 & \text { (3), 313-340 }\end{array}$ http://dx.doi.org/10.1099/00207713-16-3-313.

Sonoda, T., Kobayashi K., Ubakata, M., Osada, H., Isono, K., 1992. Absolute configuration of epiderstatin, a new glutarimide antibiotic produced by Streptomyces pulveraceus. J. Antibiot. 45 (12), 1963-1965.

Sosio, M., Bossi, E., Bianchi, A., Donadio, S., 2000. Multiple peptide synthetase gene clusters in actinomycetes. Mol. Gen. Genet. 264 (3), 213-221. http://dx.doi. org/10.1007/s004380000336.

Suárez-Estrella, F., Arcos-Nievas, M.A., López, M.J., Vargas-García, M.C., Moreno, J., 2013. Biological control of plant pathogens by microorganisms isolated from agro-industrial composts. Biol. Control 67 (3), 509-515 http://dx.doi.org/10.1016/j.biocontrol.2013.10.008.

Sugawara, R., Onuma, M., 1957. Melanomycin, a new antitumor substance from streptomycetes. II. description of the strain. J. Antibiot. 10 (4), 138-142.

Tamura, K., Stecher, G., Peterson, D., Filipski, A., Kumar, S., 2013. MEGA6: Molecular Evolutionary Genetics Analysis version 6.0. Mol. Biol. Evol. 30 (12), 2725-2729. http://dx.doi.org/10.1093/molbev/mst197.

Thakur, D., Yadav, A., Gogoi, B.K., Bora, T.C., 2007. Isolation and screening of Streptomyces in soil of protected forest areas from the states of Assam and Tripura, India, for antimicrobial metabolites. J. Mycol. Med. 17 (4), 242-249. http://dx.doi.org/10.1016/j.mycmed.2007.08.001.

Vance, E.D., Brookes, P.C., Jenkinson, D.S., 1987. An extraction method for measuring soil microbial biomass C. Soil Biol. Biochem. 19 (6), 703-707. http://dx.doi.org/10.1016/0038-0717(87)90052-6.

Wang, D., Xue, Q., Ma, Y., Wei, X., Chen, J., He, F., 2014. Oligotrophy is helpful for the isolation of bioactive actinomycetes. Indian J. Microbiol. 54 (2), 178-184. http://dx.doi.org/10.1007/s12088-014-0444-1.

Woodward, J.E., Baughman, T.A., Baring, M.R., Simpson, C.E. 2015. Comparison of three high-oleic peanut cultivars under varying field conditions in the Southwestern United States. Peanut Sci. 2015, 42, 11-17. https://doi.org/10.3146/0095-3679-42.1.11.

Yajima W., Kav N. N. V. 2006. The proteome of the phytopathogenic fungus Scl erotinia sclerotiorum. Proteomics 6, 5995-6007. https://doi.org/10.1002/pmic.20 0600424.

Yan, L.-L., Han, N.-N., Zhang, Y.-Q., Yu, L.-Y., Chen, J., Wei, Y.-Z., Li, Q.P., Tao, L., Zheng, G.-H., Yang, S.-E., Jiang C.-X., Zhang X.-D., Huang, Q., H abdin, X., Hu, Q.-B., Li, Z., Liu, S.-W., Zhang, Z.-Z., He, Q.-Y., Si1, S.-Y., Sun, C.-H., 2010. Antimycin A 18 produced by an endophytic Streptomyces albidoflavus isolated from a mangrove plant.

The Journal of Antibiotics 63 (5), 259-261. http://dx.doi.org/10.1038/ja.2010.21.

Yang, J., Xie, B., Bai, J., Yang, Q., 2012. Purification and characterization of a nitroreductase from the soil bacterium Streptomyces mirabilis. Process Biochem. 47 (5), 720-724. http://dx.doi.org/10.1016/j.procbio.2012.01.021. 